University of Nebraska - Lincoln

DigitalCommons@University of Nebraska - Lincoln

7-1992

\title{
Performance of small-seeded common bean from the second selection cycle and multiple-cross intra- and interracial populations
}

\author{
Shree P. Singh \\ Centro Internacional de Agricultura Tiopical \\ Carlos A. Urrea \\ University of Nebraska-Lincoln, currea2@unl.edu \\ Albeiro Molina \\ Centro Internacional de Agricultura Tropical \\ J. Ariel Gutierrez \\ centro Internacional de Agricultura Tropical
}

Follow this and additional works at: https://digitalcommons.unl.edu/panhandleresext

Singh, Shree P.; Urrea, Carlos A.; Molina, Albeiro; and Gutierrez, J. Ariel, "Performance of small-seeded common bean from the second selection cycle and multiple-cross intra- and interracial populations" (1992). Panhandle Research and Extension Center. 94.

https://digitalcommons.unl.edu/panhandleresext/94

This Article is brought to you for free and open access by the Agricultural Research Division of IANR at DigitalCommons@University of Nebraska - Lincoln. It has been accepted for inclusion in Panhandle Research and Extension Center by an authorized administrator of DigitalCommons@University of Nebraska - Lincoln. 


\title{
Performance of small-seeded common bean from the second selection cycle and multiple-cross intra- and interracial populations
}

\author{
Shree P. Singh, Carlos A. Urrea, Albeiro Molina, and J. Arièl Gutiérrez \\ Bean Program, Centro Internacional de Agricultura Tropical (CIAT), A.A. 6713, Cali, \\ Colombia. Received 12 September 1991, accepted 10 March 1992.
}

\begin{abstract}
Singh, S. P., Urrea, C. A., Molina, A. and Gutiérrez, J. A. 1992. Performance of small-seeded common bean from the second selection cycle and multiple-cross intra- and interracial populations. Can. J. Plant Sci. 72: 735-741. Twenty experimental lines of small-seeded common bean (Phaseolus vulgaris L.) of Middle American origin from the second cycle of selection (SCS) in multiplecross intra- and interracial populations were evaluated with two control cultivars from the first cycle of selection (FCS) derived from single-cross intraracial populations and three standard controls at three locations for $3 \mathrm{yr}$ (1988-1990) in Colombia. A $5 \times 5$ lattice design with four replications was used. Each plot consisted of four rows, $5 \mathrm{~m}$ long in the first year and $7 \mathrm{~m}$ long in the next 2 years. To develop experimental lines in both selection cycles, visual mass selection for seed yield and/or resistance to diseases in individual plants and plant-to-progeny rows was practiced in early generations. The $\mathrm{F}_{2}$ and $\mathrm{F}_{3}$ were managed by the single-pod bulk method followed by the single plant harvests $\left(\mathrm{F}_{4}\right.$ or $\left.\mathrm{F}_{5}\right)$, progeny tests $\left(F_{5}\right.$ or $\left.F_{6}\right)$, and seed increases $\left(F_{6}\right.$ or $\left.F_{7}\right)$. The $F_{4^{-}}$or $F_{5}$-derived lines were tested for seed yield in $\mathrm{F}_{7}$ or $\mathrm{F}_{8}$. Thirteen lines from the SCS outyielded both control cultivars from the FCS and one standard control. However, only two lines, A 785 and A 774, from the SCS outyielded the best standard control, cultivar Carioca, by an average of $7.7 \%$. Both lines were derived from interracial populations involving high-yielding parents possessing positive general combining ability for seed yield. Most improved lines from the SCS possessed higher yield per day and higher disease resistance. No apparent changes were recorded in days to maturity and 100-seed weight for high-yielding lines. Late-maturing lines usually had lower yield and yield per day.
\end{abstract}

Key words: Phaseolus vulgaris, small-seeded common bean, seed yield, cycles of selection, intra- and interracial crosses

Singh, S. P., Urrea, C. A., Molina, A. et Gutiérrez, J. A. 1992. Comportement des haricots à petits grains issus du second cycle de sélection à partir de croisement multiples intra et interraces. Can. J. Plant Sci. 72: 735-741. Vingt lignées expérimentales de haricot (Phaseolus vulgaris L.) de provenance mésoaméricaine, issus du second cycle de sélection (SCS) au sein de croisements multiples intra et inter-races, ont été comparés à deux cultivars témoins de premier cycle de sélection (PCS) dérivés de croisements simples intraraciaux et à trois cultivars standards. Les essais ont été conduits pendant 3 ans (1988-1990) à trois endroits en Colombie. Un dispositif expérimental en réseau carré $5 \times 5$, à quatre répétitions, était utilisé. Chaque parcelle consistait en 4 lignes de $5 \mathrm{~m}$ dans la première année et de $7 \mathrm{~m}$ dans les deux autres. Dans les deux cycles de sélection, pour obtenir les lignées expérimentales, on a eu recours pour commencer à la sélection massale visuelle sur le rendement en grain ou sur la résistance aux maladies, parmi les plantes individuelles et les plantes-lignes. En $F_{2}$ et en $F_{3}$ la méthode de sélection différée (bulk), une gousse par plante, était utilisée, suivie, en $\mathrm{F}_{4}$ ou $\mathrm{F}_{5}$, de la sélection de plantes individuelles, en $\mathrm{F}_{5}$ ou $\mathrm{F}_{6}$, de tests sur descendance et en $\mathrm{F}_{6}$ ou $F_{7}$, de cultures de multiplication. Les lignées $F_{4}$ ou $F_{5}$ étaient évaluées sur le rendement grainier en $F_{7}$ ou $F_{8}$. Treize lignées du SCS surpassaient en rendement les cultivars témoins de PCS, de même qu'un cultivar standard. Toutefois, seulement deux lignées, A 785 et A 774, surpassaient le meilleur témoin standard Carioca ( $7,7 \%$ en moyenne). Toutes deux provenaient de populations interraciales impliquant des parents à haut rendement possédant une aptitude générale à la combinaison pour le rendement

Can. J. Plant Sci. 72: 735-741 (July 1992) 
granier. La plupart des lignées améliorées de SCS affichaient un rendement par jour de croissance plus élevé et une plus forte résistance aux maladies. On n'a observé aucun changement notable en ce qui concerne la précocité de maturation (j) et le poids de 100 grains chez les lignées à haut rendement. Les lignées tardives avaient habituellement un rendement absolu et un rendement/jour plus bas.

Mots clés: Phaseolus vulgaris L., haricot àpetits grains, rendement grainier, cycle de sélection, croisements intra et interraciaux

Six races of common bean (Phaseolus vulgaris L.), three each from Middle America and Andean South America, have been identified on the basis of morphological, agronomic, adaptive, and molecular characteristics (Singh et al. 1991a). Traditionally, breeding has been mostly limited to exploitation of genetic variability available within races, gene pools, or seed classes (Singh 1991, 1992). Moreover, emphasis has been on breeding for tolerance to productionlimiting factors, especially diseases. Breeding for increased seed yield per se and utilization of germplasm across races (Singh et al. 1991a) and gene pools (Singh 1989) was usually not practiced until recently (Kelly and Adams 1987). This was because of insufficient knowledge about combining ability of parents belonging to different races and gene pools, and problems in recovering desirable plant, seed, and adaptation characteristics from interracial populations (Singh 1991, 1992). Moreover, $F_{1}$ hybrid dwarfism, weakness, or incompatibility (Shii et al. 1980; Singh and Gutiérrez 1984; Gepts and Bliss 1985; Vieira et al. 1989) and cripples or viruslike foliage symptoms (Coyne 1965; Singh and Molina 1991) occur in some interracial populations, especially those derived from crosses between Andean and Middle American common bean germplasm.

Small-seeded $(<25 \mathrm{~g} / 100$ seeds $)$ common beans belong to the race Mesoamerica (Singh et al. 1991a). They are adapted to relatively warmer tropical lowlands, occupy the largest hectarage ( $>6$ million ha) in Latin America, and are also grown in Canada, the USA, and other parts of the world. Among these, indeterminate cultivars of bush growth habits II and III (Singh 1982) of black, cream ('mulatinho'), cream-striped ('carioca'), and red seed colors are more popular in the tropics. Of these, cream and cream-striped types are principally grown in Brazil. Breeding at CIAT for these two commercial seed classes was initiated in 1978, and two cycles of improvement were completed by 1988. Variation in the first cycle was mostly generated by single crosses made in 1978-1979. Resistance to bean common mosaic virus (BCMV), anthracnose caused by Colletotrichum lindemuthianum (Sacc. \& Magn.), and angular leaf spot caused by Phaeoisariopsis griseola (Sacc.) Ferraris was emphasized. Visual selection was practiced for seed yield and/or resistance to diseases. Variation in the second cycle was mostly generated by multiple crosses made in 1982-1984. In addition to the above three diseases, resistance to common bacterial blight caused by Xanthomonas campestris pv. phaseoli (Smith) Dye was also selected. Furthermore, selection for seed yield was based on replicated trials in $\mathrm{F}_{7}$ or $\mathrm{F}_{8}$. However, in both cycles, crosses were primarily made among parents within the race Mesoamerica. The objective of this study was to compare the performance of some lines from the second cycle with the standard controls and two control cultivars from the first selection cycle. Also, the importance of a few lines derived from interracial populations made in the second selection cycle was determined.

\section{MATERIALS AND METHODS}

Twenty lines developed from the second cycle of selection (SCS); two control cultivars, Rio Doce (A 247) and EMGOPA-Ouro (A 295) from the first cycle of selection (FCS) that had been released for commercial cultivation in Brazil; and three standard controls (Carioca, IPA 6, and ICA Pijao) were compared. Carioca is a high-yielding cultivar of 
unknown origin first released by the Instituto Agronômico de Campinas, São Paulo, that has been extensively grown for over $15 \mathrm{yr}$. It possesses cream-striped seed color and indeterminate type III growth habit. IPA 6 is a high-yielding cultivar developed and released by the Instituto Agropecuário Pernambucano, Recife, in the mid-1980s. It has cream seed color and indeterminate type III growth habit. Thus, these controls represented two major non-black seed classes extensively grown and consumed in Brazil. Moreover, except for A 785 (black-seeded), all other experimental lines from the SCS were of either cream or creamstriped seed color. ICA Pijao is high-yielding, has an indeterminate type II growth habit, and is a black-seeded cultivar developed and released by the Instituto Colombiano Agropecuario in Colombia. It has been grown in some Latin American countries for several years and has been used as an international check.

All 25 entries were resistant to BCMV and possessed indeterminate growth habit II or III. Lines A 790, A 769, A 767, A 295, and A 247 were derived from single-cross intraracial populations. All other lines were selected from multiple-cross populations. Popular landraces; sources of resistance to BCMV, anthracnose, angular leaf spot, common bacterial blight, drought, and low soil fertility; and improved experimental lines from CIAT and other programs in Latin America were used as parents for hybridization. Most parents were small-seeded ( $<25 \mathrm{~g} / 100$ seeds) and possessed characteristics of the race Mesoamerica. Moreover, a few parents of known general combining ability for seed yield, possessing medium-sized ( $25-40 \mathrm{~g} / 100$ seeds) seed, from the Mexican highland race Durango were also included. An average of $30 F_{1}$ seeds were produced for all crosses in both cycles by hand emasculation and pollinations. Early segregating generations were space-planted in unreplicated plots and visual selection in individual plants and in plant-to-progeny rows was practiced for seed yield, other seed characteristics, and/or resistance to diseases. Populations were handled by the single pod bulk method in $F_{2}$ and $F_{3}$, followed by individual plant harvests $\left(\mathrm{F}_{4}\right.$ or $\left.\mathrm{F}_{5}\right)$, progeny tests $\left(F_{5}\right.$ or $\left.F_{6}\right)$, seed increases $\left(F_{6}\right.$ or $\left.F_{7}\right)$, and yield trials $\left(\mathrm{F}_{7}\right.$ or $\left.\mathrm{F}_{8}\right)$. Moreover, evaluation and selections were carried out by alternating generations among three contrasting locations (Palmira, Popayán, and Quilichao) often used for common bean improvement in Colombia.

The 25 entries were grown in a $5 \times 5$ lattice design with four replications at CIAT farms at
Palmira ( $1000 \mathrm{~m}$ elevation with mean growing temperature of $24^{\circ} \mathrm{C}$; fine-silty, mixed, isohyperthermic Aquic Hapludoll soil with $\mathrm{pH} 7.5$ ), Quilichao (990 m elevation with mean growing temperature of $24^{\circ} \mathrm{C}$; very-fine kaolinitic, isohyperthermic Plinthic Kandiudox soil with $\mathrm{pH} 4.5$ ), and Popayán (1750 $\mathrm{m}$ elevation with mean growing temperature of $18^{\circ} \mathrm{C}$; fine-loamy, mixed, isothermic Typic (Andic) Dystropept soil with $\mathrm{pH}$ 4.5), Colombia, over three consecutive years, 1988-1990. All three sites are located between $2^{\circ} 25^{\prime}$ and $3^{\circ} \mathrm{N}$ latitude. Soils at Popayán and Quilichao are deficient in phosphorus and possess toxic levels of aluminum. It is not possible to grow common bean at these two sites without adding lime and fertilizer. Although fields used for yield trials had been used for growing common bean nurseries for a few years, $2000 \mathrm{~kg} \mathrm{ha}^{-1}$ of lime $4 \mathrm{wk}$ before sowing and $300 \mathrm{~kg} \mathrm{ha}^{-1}$ of a fertilizer mixture $(10 \mathrm{~N}: 30 \mathrm{P}: 10 \mathrm{~K})$ were applied, both at Popayán and Quilichao, at the time of sowing in 1988. No lime or fertilizer was applied in 1989 or 1990 at either location. This was done to provide moderate stress for soil fertility in order to approximate actual growing conditions in Latin America. Each plot consisted of four rows, $5 \mathrm{~m}$ long in the first year and $7 \mathrm{~m}$ long in the next 2 years. Spacing between rows at Palmira and Quilichao was $0.6 \mathrm{~m}$ and at Popayán $0.5 \mathrm{~m}$. An average density of 200 000 plants ha ${ }^{-1}$ was obtained at each location. All sowings at Popayán were under rainfed conditions. Supplemental irrigations were applied at Palmira and Quilichao whenever required. At Popayán, there was a natural occurrence of anthracnose, and at Quilichao angular leaf spot and common bacterial blight infected the plots. Days to maturity were recorded. Two central rows, with head borders of $0.5 \mathrm{~m}$ on either side, were harvested at maturity for measurement of seed yield $(\mathrm{kg}$ $\mathrm{ha}^{-1}$ ) and 100 -seed weight (g), and both were adjusted to $14 \%$ moisture by weight. Yield per day was calculated by dividing yield per hectare by number of days to maturity. Data were tested for homogeneity of error variances (Bartlett 1947) before performing combined analysis of variance using a mixed model (McIntosh 1983) whereby lines were considered fixed and locations and years were considered random. The Statistical Analysis System Institute, Inc. package for statistical analyses (SAS Institute, Inc., Cary, North Carolina) was used for data analyses. Data for reaction to diseases were recorded on a 1-9 scale, where $1=$ immune and $9=$ very susceptible (Schoonhoven and Pastor Corrales 1987). 
RESULTS AND DISCUSSION

Mean squares due to entries, locations, and years were significant $(P<0.05)$ for seed yield and 100-seed weight (analysis not shown). Values for entries and locations for days to maturity and entries and years for yield per day were also significantly different $(P<0.05)$. Entry $\times$ location interactions were significantly different $(P<0.05)$ for all traits and entry $\times$ year interactions were nonsignificant $(P>0.05)$ for all traits except 100 -seed weight. Thus, the three locations used to develop and evaluate common bean lines were markedly different. Use of such locations representative of bean production regions is essential for selection of high- and stable-yielding cultivars. Nonetheless, significant entry $\times$ location interactions for all traits including seed yield suggested that the performance of entries varied somewhat from location to location. This occurred in spite of the fact that the same three locations were used to develop lines throughout the breeding process and the filial generations were alternated among locations. Being near the equator, temperature fluctuations are relatively small during the year at all three locations. Thus, differences among locations in rainfall, soil fertility, agronomic management of trials, and composition and pressure of pathogen populations of anthracnose, angular leaf spot, common bacterial blight, and other biotic factors might be largely responsible for significant entry $\times$ location interactions for all traits in this study.

Mean seed yield (Table 1), yield per day, and 100-seed weight were the lowest at Popayán, although days to maturity was the highest (data not shown). Palmira had the highest seed yield and Quilichao the highest 100 -seed weight. Yield per day at Palmira and Quilichao was similar. Experimental lines from the SCS in general, and its highest yielding entries in particular, possessed relatively higher 100 -seed weight and yield per day and relatively lower disease scores (Table 1).

Thirteen entries from the SCS outyielded the two controls from the FCS by an average of $600 \mathrm{~kg} \mathrm{ha}^{-1}$ (i.e., $17 \%$ ). The gains over ICA Pijao were similar. Nonetheless, yields of ICA Pijao at Palmira and Quilichao were much higher than at Popayán. Over $50 \%$ of the reduction in yield of ICA Pijao at Popayán was due to its extreme susceptibility to anthracnose (Table 1). That demonstrated the value of incorporating resistance to such a destructive disease as anthracnose in new experimental lines developed for cool, humid bean-growing environments. Of 13 entries from the SCS outyielding the two controls from the FCS, only two (A 769 and FEB 170) were of indeterminate erect growth habit II (Singh 1982). Usually, these type II cultivars yield less than their prostrate type III counterparts, and it has been difficult to improve the yield of erect type I and II cultivars in the tropics (Laing et al. 1984; Nienhuis and Singh 1985).

Yield gains over IPA 6 and Carioca, the two standard controls representing cream ('mulatinho') and cream-striped ('carioca') commercial seed classes, respectively, and extensively grown in Brazil, were relatively small. Only A 785 (black-seeded) and A 774 (cream-seeded) significantly $(P<0.05)$ outyielded Carioca, by an average of $7.7 \%$. As noted earlier, Carioca is a landrace of unknown origin and has been in commercial production in Brazil for $15 \mathrm{yr}$. It is very productive, is tolerant to marginally fertile soils, and shows moderate levels of tolerance to most diseases of major economic importance. Those may be some of the reasons for its widespread cultivation (estimated area under cultivation in Brazil alone is over 1 million ha). IPA 6 is among the newer generation of improved cultivars from the northeastern state of Pernambuco, released in the mid-1980s. There are several reasons why few entries outyielded Carioca. First, Carioca itself and most other high-yielding cultivars of this group belonging to the race Mesoamerica that were used as parents in crosses have negative general combining ability (GCA) for seed yield (Nienhuis and Singh 1988a). Thus, they would have contributed little useful additive genetic variance for seed yield upon crossing with germplasm 
Table 1. Mean seed yield, yield per day, 100-seed weight, days to maturity, and score for anthracnose of common bean lines from the second cycle of selection (SCS) and first cycle of selection (FCS) and standard controls evaluated for 3 yr (1988-1990) at three locations in Colombia

\begin{tabular}{|c|c|c|c|c|c|c|c|c|c|}
\hline \multirow[b]{2}{*}{ Identification } & \multirow{2}{*}{$\begin{array}{c}\text { Growth } \\
\text { habit }\end{array}$} & \multicolumn{3}{|c|}{ Seed yield } & \multirow[b]{2}{*}{ Mean } & \multirow{2}{*}{$\begin{array}{l}\text { Yield } \\
d^{-1}\end{array}$} & \multirow{2}{*}{$\begin{array}{c}100 \text {-seed } \\
\text { weight }\end{array}$} & \multirow{2}{*}{$\begin{array}{l}\text { Days to } \\
\text { maturity }\end{array}$} & \multirow[b]{2}{*}{ Anthracnose ${ }^{2}$} \\
\hline & & Palmira & Quilichao & Popayán & & & & & \\
\hline SCS lines & & & \multicolumn{3}{|c|}{ (kg/ha) } & \multicolumn{3}{|c|}{$(\mathrm{g})$} & \\
\hline A 785 & III & 2602 & 2124 & 1849 & 2192 & 29.7 & 25.0 & 80.8 & 5.6 \\
\hline A 774 & III & 2587 & 2267 & 1694 & 2183 & 31.4 & 22.6 & 76.5 & 3.2 \\
\hline A 775 & III & 2472 & 2246 & 1480 & 2066 & 29.3 & 21.7 & 76.9 & 4.6 \\
\hline FEB 127 & III & 2449 & 1940 & 1667 & 2018 & 26.2 & 24.2 & 84.5 & 1.6 \\
\hline FEB 166 & III & 2463 & 1978 & 1601 & 2014 & 27.6 & 22.9 & 80.0 & 4.5 \\
\hline A 787 & III & 2263 & 2180 & 1507 & 1983 & 28.0 & 22.8 & 77.8 & 2.5 \\
\hline A 777 & III & 2037 & 2110 & 1591 & 1912 & 26.7 & 23.8 & 79.0 & 1.8 \\
\hline FEB 170 & II & 2016 & 2115 & 1475 & 1869 & 26.5 & 19.9 & 77.1 & 4.3 \\
\hline А 796 & III & 1739 & 1994 & 1789 & 1840 & 25.6 & 19.7 & 78.8 & 2.0 \\
\hline A 765 & III & 1782 & 2081 & 1618 & 1827 & 24.0 & 18.0 & 83.9 & 4.8 \\
\hline A 795 & III & 2096 & 1913 & 1464 & 1824 & 23.3 & 21.8 & 85.2 & 5.5 \\
\hline A 784 & II & 2001 & 1868 & 1525 & 1798 & 25.3 & 19.5 & 78.3 & 1.6 \\
\hline A 794 & III & 2183 & 1804 & 1373 & 1787 & 22.9 & 22.6 & 85.1 & 2.5 \\
\hline A 791 & II & 1881 & 1805 & 1664 & 1783 & 24.0 & 20.3 & 82.2 & 4.3 \\
\hline A 772 & III & 2025 & 1892 & 1334 & 1751 & 24.0 & 18.5 & 80.2 & 2.0 \\
\hline A 786 & III & 1880 & 1806 & 1413 & 1700 & 23.6 & 26.2 & 80.1 & 1.7 \\
\hline FEB 154 & II & 1920 & 1790 & 1346 & 1685 & 23.8 & 19.2 & 77.5 & 3.8 \\
\hline A $790^{y}$ & III & 2186 & 1886 & 1680 & 1918 & 26.5 & 22.2 & 79.5 & 1.9 \\
\hline A $769^{y}$ & II & 2142 & 2069 & 1317 & 1843 & 26.1 & 18.5 & 75.8 & 2.0 \\
\hline A $767^{y}$ & II & 1979 & 1904 & 1402 & 1762 & 25.0 & 18.7 & 76.7 & 2.1 \\
\hline \multicolumn{10}{|c|}{ Standard controls } \\
\hline Carioca & III & 2293 & 2047 & 1751 & 2030 & 28.2 & 23.7 & 78.7 & 1.6 \\
\hline IPA 6 & III & 1995 & 1970 & 1716 & 1894 & 26.1 & 17.2 & 79.3 & 5.5 \\
\hline ICA Pijao & II & 2090 & 1621 & 997 & 1569 & 21.4 & 18.5 & 79.4 & 7.4 \\
\hline \multicolumn{10}{|l|}{ FCS controls } \\
\hline A $295^{y x}$ & III & 1969 & 1883 & 1183 & 1678 & 23.3 & 18.4 & 79.6 & 4.1 \\
\hline A $247^{y x}$ & II & 2035 & 1358 & 1216 & 1536 & 22.1 & 20.2 & 76.5 & 2.5 \\
\hline Mean & & 2124 & 1946 & 1506 & 1859 & 25.6 & 21.1 & 79.6 & \\
\hline $\operatorname{LSD}(0.05)$ & & 307.4 & 307.4 & 307.4 & 123.8 & 1.7 & 0.5 & 0.7 & \\
\hline
\end{tabular}

${ }^{2}$ Mean over 3 yr recorded at Popayán. Scored on a $1-9$ scale where $1=$ immune and $9=$ very susceptible.

$\mathbf{y}_{\text {Derived from single-cross populations. }}$

${ }^{x}$ A 295 and A 247 are commercially grown in Brazil under the name EMGOPA-Ouro and Rio Doce, respectively.

of similar origins. Second, there is insufficient genetic variation because of crossing among parents belonging to the same gene pool and races (Singh et al. 1989b). Third, highyielding parents from other races possessing positive GCA for yield (Nienhuis and Singh 1988a; Singh et al. 1992), that were essential for developing high-yielding lines (Singh et al. 1989a), were not utilized in most crosses. Fourth, direct measurement of yield per se, based on replicated trials, which was found to be an effective selection criterion (Nienhuis and Singh 1988b; Singh and
Gutiérrez 1990; Singh et al. 1990), was not used on the early generations. Visual mass selection for seed yield and resistance to diseases was usually practiced in early generations. Yield testing was done in $F_{7}$ or $F_{8}$ for $\mathrm{F}_{4^{-}}$or $\mathrm{F}_{5}$-derived lines and, hence, it is likely that some high-yielding recombinants were lost in the process of selection (Sneep 1977). Had information on combining ability (Nienhuis and Singh 1986, 1988a; Singh et al. 1992) been taken into account at the time of parental selection and hybridization, had interracial rather than intraracial crosses 
been made, and had early-generation yield testing (Singh 1991, 1992) been imposed along with simultaneous screening and selection for disease resistance, perhaps more entries would have outyielded and yielded much higher than Carioca, the best cultivar used as a control. Some support for this could be obtained by examining the pedigree of the three highest yielding entries, A 785, A 774, and A 775. A 785 was derived from an interracial population (BZ 5838) involving eight parents. A 774 and A 775 are sister entries originating from another interracial population (BZ 5687) comprising five parents. Both interracial populations involve A 375 and A 445 as parents known to possess positive GCA for seed yield (Nienhuis and Singh 1986, 1988a). Both of these parents have characteristics of race Durango. Moreover, the highest-yielding entry, A 785, also had two additional parents, namely, A 213 and BAT 477, with positive GCA for seed yield (Nienhuis and Singh 1988a), although they possessed characteristics of the same smallseeded race, Mesoamerica, as Carioca. Since some other entries (e.g., A 790, A 777, A 796, A 795, A 786, and FEB 154) had one or more parents with positive GCA in their pedigree, but did not outyield Carioca, this would suggest that not all such entries would have high yield. In addition to high yield and possession of positive GCA for seed yield, parents involved in a cross should be from different races to assure large additive genetic variance in hybrid populations. Moreover, seed yield should be used as a direct selection criterion to identify high-yielding recombinants among and within such populations.

The low seed yield of late-maturing entries such as A 765, A 794, A 795, and FEB 127 was largely due to their relatively reduced yield per day (Table 1). Thus, breeding for delayed maturity (Laing et al. 1984) per se may not necessarily result in high yield. Instead, simultaneous selection may need to be exercised for both delayed maturity and high seed yield. A 774 was about as early as A 247 , but yielded over $600 \mathrm{~kg} \mathrm{ha}^{-1}$ more, principally because of its higher yield per day. Other high-yielding entries usually also had higher yield per day. However, it is not known whether or not yield per day itself could be an effective selection criterion for improving the productivity potential of common bean in the tropics.

Mean disease score for angular leaf spot ranged from 3.5 for FEB 166 to 6.0 for ICA Pijao. Similarly, values for common bacterial blight ranged from 5.2 to 8.0 for these same entries, respectively (data not shown). Thus, in spite of screening and selection under field conditions at Quilichao for two cycles, only moderate levels of resistance could be incorporated for these two important diseases into entries from the SCS. Different and better sources of resistance and alternative screening and selection methods need to be tried in the future. On the other hand, after two cycles of selection, levels of resistance to anthracnose in entries from the SCS were comparatively higher than those of angular leaf spot and common bacterial blight. This could be because much higher levels of resistance (immunity) are available for anthracnose (Singh et al. 1991b), resistance is controlled by major genes, and environments at Popayán are very conducive to the development of anthracnose, thus facilitating screening and selection for resistance. In over 20000 germplasm bank accessions screened thus far, only intermediate levels of resistance have been found for angular leaf spot (M. A. Pastor Corrales, pers. commun. 1991), and it is usually more difficult to screen and select for this disease (Singh et al. 1991b). Although extremely high levels of resistance to common bacterial blight are found in tepary bean (Phaseolus acutifolius A. Gray), only intermediate levels of resistance are available in common bean (Silva et al. 1989). Also, when resistance to multiple diseases is sought or needs to be combined with high yield and other desirable traits, intensive selection for any single factor is usually not exercised in our breeding program. That could have been one cause of relatively low levels of resistance, especially for angular leaf spot and common bacterial blight, in entries from the SCS. 


\section{ACKNOWLEDGMENTS}

We are very grateful to Henry Terán for statistical analysis of data, Aracelly Fernández for typing of the manuscript, and Bill Hardy for editorial assistance.

Bartlett, M. S. 1947. The use of transformations. Biometrics 3: 39-52.

Coyne, D. P. 1965. A genetic study of "crippled" morphology resembling virus symptoms in Phaseolus vulgaris L. J. Hered. 56: 162-163.

Gepts, P. and Bliss, F. A. 1985. $F_{1}$ hybrid weakness in the common bean: Differential geographic origin suggests two gene pools in cultivated bean germplasm. J. Hoed. 76: 447-450.

Kelly, J. D. and Adams, M. W. 1987. Phenotypic recurrent selection in ideotype breeding of pinto beans. Euphytica 36: 69-80.

Laing, D. R., Jones, P. J. and Davis, J. H. C. 1984. Common bean (Phaseolus vulgaris L.). Pages 305-351. in P. R. Goldsworthy and N. M. Fisher, eds. The physiology of tropical field crops. John Wiley \& Sons, New York, NY.

McIntosh, M. S. 1983. Analysis of combined experiments. Agron. J. 75: 153-155.

Nienhuis, J. and Singh, S. P. 1985. Effects of location and plant density on yield and architectural traits in dry beans. Crop Sci. 25: 579-584.

Nienhuis, J. and Singh, S. P. 1986. Combining ability analyses and relationships among yield, yield components, and architectural traits in dry bean. Crop Sci. 26: 21-27.

Nienhuis, J. and Singh, S. P. 1988a. Genetics of seed yield and its components in common bean (Phaseolus vulgaris L.) of Middle-American origin. I. General combining ability. Plant Breed. 101: 143-154.

Nienhuis, J. and Singh, S. P., 1988b. Genetics of seed yield and its components in common bean (Phaseolus vulgaris L.) of Middle-American origin. II. Genetic variance, heritability and expected response from selection. Plant Breed. 101: 155-163. Schoonhoven, A. van and Pastor Corrales, M. A. (compilers). 1987. Standard system for the evaluation of bean germplasm. Int. Ctr. for Tropical Agric. (CIAT), Cali, Colombia.

Shii, C. T., Mok, M. C., Temple, S. R. and Mok, D. W. S. 1980. Expression of developmental abnormalities in hybrids of Phaseolus vulgaris L.: interaction between temperature and allelic dosage. J. Hered. 71: 218-222.

Silva, L. O., Singh, S. P., and Pastor-Corrales, M. A. 1989. Inheritance of resistance to bacterial blight in common bean. Theor. Appl. Genet. 78: 619-624. Singh, S. P. 1982. A key for identification of different growth habits of Phaseolus vulgaris $\mathrm{L}$. Annu. Rep. Bean Improv. Coop. 25: 92-95.
Singh, S. P. 1989. Patterns of variation in cultivated common bean (Phaseolus vulgaris, Fabaceae). Econ. Bot. 43: 39-57.

Singh, S. P. 1991. Breeding for seed yield. Pages 383-443. in A. van Schoonhoven and O. Voysest, eds., Common beans: research for crop improvement. CAB Intl., Wallingford, U.K. and CIAT, Cali, Colombia.

Singh, S. P. 1992. Common bean improvement in the tropics. Plant Breed. Rev. 10: (in press.) Singh, S. P., Cajiao, C., Gutiérrez, J. A., García, J., Pastor Corrales, M. A. and Morales, F. J. 1989a. Selection for seed yield in inter-gene pool crosses of common bean. Crop Sci. 29: 1126-1131.

Singh, S. P., Gepts, P. and Debouck, D. 1991a. Races of common bean (Phaseolus vulgaris Fabaceae). Econ. Bot. 45: 379-396.

Singh, S. P. and Gutiérrez, J. A. 1984. Geographical distribution of $\mathrm{DL}_{1}$ and $\mathrm{DL}_{2}$ genes causing hybrid dwarfism in Phaseolus vulgaris L., their association with seed size, and their significance to breeding. Euphytica 33: 337-345.

Singh, S. P. and Gutiérrez, J. A. 1990. Selection for seed yield in three plant densities of two population types of common bean, Phaseolus vulgaris L. Euphytica 51: 173-178.

Singh, S. P., Lépiz R., Gutiérrez, J. A., Urrea, C., Molina, A. and Terán, H. 1990. Yield testing of early generation populations of common bean. Crop Sci. 30: 874-878.

Singh, S. P. and Molina, A. 1991. Occurrence of deformed leaflets (virus-like symptoms) in segregating generations of interracial populations of common bean. Annu. Rep. Bean Improv. Coop. 34: 134-135.

Singh, S. P., Pastor-Corrales, M. A., Molina, A. and Urrea, C. 1991b. Alternate, independent and simultaneous selection for resistance to anthracnose and angular leaf spot of common bean and effects on seed yield. Plant Breed. 106: 312-318. Singh, S. P., Urrea, C., Gutiérrez, J. A. and García, J. 1989b. Selection for yield at two fertilizer levels in small-seeded common bean. Can. J. Plant Sci. 69: 1011-1017.

Singh, S. P., Terán, H., Molina, A. and Gutiérrez, J. A. 1992. Combining ability for seed yield and its components in common bean of Andean origin. Crop Sci. 32: 81-84.

Sneep, J. 1977. Selection for yield in early generations of self-fertilizing crops. Euphytica 26: 27-30.

Vieira, A. L., Patto Ramalho, M. A. and dos Santos, J. B. 1989. Crossing incompatibility in some bean cultivars utilized in Brazil. Rev. Brasil. Genet. 12: 169-171. 